\title{
PELATIHAN TEKNIK PENGELASAN BAGI MASYARAKAT USIA PRODUKTIF UNTUK PRODUK REAL ESTATE, KANTOR PEMERINTAHAN DAN PELAYANAN MASYARAKAT
}

\section{WELD TRAINING FOR AGE PRODUCTIVE COMMUNITY TO MAKING PRODUCT FOR REAL ESTATE, GOVERNMENT OFFICE, AND COMMUNITY SERVICES}

\author{
Oleh: \\ Anizar Indriani ${ }^{1}$, Yovan Witanto ${ }^{2}$ \\ ${ }^{1}$ Program Studi Teknik Elektro Fakultas Teknik Universitas Bengkulu \\ ${ }^{2}$ Program Studi Teknik Mesin Fakultas Teknik Universitas Bengkulu
}

\begin{abstract}
Welding process become a major part for small and large industries. Large industries using welding processes for cutting process plates, connecting plates, connecting pipelines and other components of the repair process. For small industries, welding process is used to maintenance and repair the automotive components industry that damaged, the manufacture of household appliances, office or public billboards. The demand for the product of the welding process is increasing depend of area developing such as for home appliances, office or public billboard is very high demand due to the increase of residential property, real eastate, development and other areas of the city. The demand of the welding process product can not much utilized in Central Bengkulu district, where orders for the manufacture of a product housing, offices or billboards only mastered by a few workshops. High demand, the availability of garages or welding industries is few that make employment opportunities are very high. But this demand needs to be supported by human resources capable of using a welding machine. In this community service given basic training in welding techniques to help people in Central Bengkulu especially Talang Empat and Taba Terunjam in exploiting existing this opportunities. Training provided is use of the welding machine to make a trellis, fence or a seat with the type of welding machine capable of TIG or MIG welding. The results of welding training shows that people who can not follow the formal and informal education has a high desire for this training. This is to improve they skill, economy and living standards by utilizing the welding knowledge to create new jobs or working with existing workshops.
\end{abstract}

Keywords: Fence, Trellis, Welding, Productive Age, Training

\section{PENDAHULUAN}

Pengembangan wilayah membutuhkan banyak dukungan baik dari segi sumber daya alam, sumber daya manusia juga sumber daya lain agar wilayah tersebut dapat berkembang dan berdiri sendiri membangun wilayahnya. Tingkat kebutuhan wilayah pengembangan 
sangat besar terutama dalam hal infrastruktur, sarana dan prasarana. Satu kebutuhan yang sangat cepat perkembangan dan dibutuhkan masyarakat adalah perumahan, perkantoran dan informasi-informasi pembangunan. Perumahan dan perkantoran memerlukan peralatan dalam membuat kebutuhan pengamanan, interior dan ekterior bangunan. Informasi pembangunan pada baliho-baliho yang dipasang dijalan-jalan, bangunan ataupun pohonpohon. Peralatan yang dibutuhkan itu berupa pagar minimalis, teralis pengaman rumah dan kantor, pagar perkantoran agar tidak diganggu oleh makluk lain, besi penyangga baliho untuk informasi pembangunan dan lainnya.

Peralatan ini dibuat dengan menggunakan mesin las, gerinda, mesin bor, mesin poles dan mesin lainnya. Penggunaan peralatan ini memerlukan skill dan keahlian khusus dimana tidak semua orang dapat menggunakan peralatan ini. Pembelajaran penggunaan peralatan ini biasanya didapat dibangku sekolah kejuruan atau balai latihan keterampilan. Bagi masyarakat yang kurang mampu, hal ini susah mereka dapatkan yang menyebabkan banyaknya pengangguran atau angka kerja yang tidak memiliki skill yang baik.

Untuk mengatasi hal ini dan juga untuk membantu pemerintahan daerah dalam mempersiapkan sumber daya manusianya agar ikut menikmati pembangunan dan berkehidupan yang layak maka dilakukan pelatihan dasar penggunaan mesin las untuk membuat produk yang sederhana seperti pagar, teralis, kursi dan alat-alat rumah tangga lainnya. Setelah pelatihan ini para peserta akan mampu membuka lapangan kerja sendiri atau bekerja dengan bengkel-bengkel atau industri kecil yang ada di daerah ini. Ini akan ikut membantu perekonomian daerah dan juga nasional.

Permintaan akan pagar rumah dan kantor, teralis rumah dan baliho yang tinggi pada daerah yang sedang mengalami pemekaran (pengembangan) menjadi suatu nilai keuntungan yang harus dimanfaatkan. Permasalah yang terjadi adalah ketidaksiapan sumber daya manusia setempat dalam memanfaatkan hal ini yang disebabkan oleh kemampuan ekonomi masyarakat yang rendah, ilmu pengetahuan yang kurang dan juga tidak adanya media pendukung bagi mereka untuk belajar.

Pengelasan merupakan suatu proses penyambungan dua buah logam atau lebih menjadi satu dengan memanfaatkan panas atau tekanan (Harsono, dkk, 2008) (Suharto, 1991). Proses pengelasan memerlukan media pemanas untuk mencairkan fluks atau elektroda yang ada sehingga terjadi penyatuan dua komponen yang akan dilas. Proses pengelasan dapat melakukan proses pemotongan pelat, penyambungan pelat, pemotongan dan penyambungan pipa, memperbaiki komponen mesin yang rusak atau patah dan lainnya.

Berdasarkan jenis pemanasannya proses pengelasan dikelompokan menjadi 3 macam yaitu:

1. Pengelasan tekan.

2. Pengelasan dengan pemanasan logam pengisi.

3. Patri.

Dimana sumber panas pada proses pengelasan didapatkan dari gas, listrik (Arifin, 1997), tekanan dan lainnya. Berdasarkan sumber panas dan cara pengelasan terdiri atas:

1. Mekanik 


\section{Listrik}

3. Kimia

4. Pengelasan tekanan (Pressure Welding)

5. Pengelasan Cair (Fusion welding)

Hal-hal yang harus diperhatikan dalam proses pengelasan adalah:

1. Jenis sambungan las.

2. Elektroda pengelasan

3. Jenis material yang akan dilas.

4. Sumber energi pengelasan.

Penyambungan produk las memerlukan suatu bagian yang dikenal dengan sebutan kampuh, dimana kampuh terdiri atas kampuh U, K, V, tunggal dan ganda. Penyambungan las terdiri atas sambungan tumpu, sudut, tumpang, tekuk dan T. Semua tipe sambungan dan kampuh ini memiliki kelebihan dan kekurangan yang meliputi kekuatan sambungan, kekerasan hasil penyambungan, banyaknya elektroda yang dibutuhkan dan kualitas hasil pengelasan.

Pemilihan sambungan dan kampuh yang baik akan menghasilkan produk dengan kualitas tinggi. Dimana kualitas hasil pengelasan diatur oleh standar las seperti AWS (American Welding Society), ASTM (American Society Testing Material) dan standar lainnya. Pengelasan setiap produk berbeda tipe dan alat yang akan digunakan, dimana berdasarkan material yang digunakan mesin las ada jenis TIG dan MIG. Pengelasan pipa biasa dengan pipa stainless steel memerlukan mesin las dengan tipe berbeda. Dari prosesnya pengelasan meliputi pengelasan patri (patri nyala, celup, tahanan, infra merah, dapur, induksi), pengelasan gas (asitelin, oksiasitelin, oksihidrogen), pengelasan tahanan (las titik, kampuh, proyeksi, tumpu, nyala dan perkussion), pengelasan busur dan elektroda karbon (busur terlindung, titik busur, gas inert, busur terendam, lantak, terak elektro).

Proses pengelasan memerlukan kawat las (elektroda) yang terdiri dari elektroda dan pelindung elektroda. Dimana elektroda itu mengacu pada standar standar AWS (American Welding Society) dan ASTM (American Society Testing Material). Satu contoh elektroda adalah E6013 yang berarti elektroda jenis las busur listrik dengan nilai tegangan tarik 60.000 psi, satu posisi pengelasan dan 3 elektroda menggunakan arus AC/DC.

Material las terdiri atas material steel, VCN, VCL dan metal lainnya (Amanto, 1999). Dimana pengaruh jenis pengelasan yang digunakan akan mempengaruhi kekuatan atau kekerasan produk las yang dihasilkan (Ahmad dan Johnny, 1994).

Dengan pengabdian masyarakat ini, masyarakat usia produktif akan diberi bekal pengetahuan menggunakan peralatan untuk pengelasan, pengecatan dan lainnya agar mereka dapat menggunakan pengetahuan tersebut untuk membuka usaha dalam bidang pengelasan. Masalah utama yang akan diselesaikan disini adalah: Bagaimana mengupayakan 
keterampilan bagi anak sekolah dan remaja putus sekolah. Sementara uraian masalah yang akan dipecahkan diantaranya adalah:

1. Bagaimana mengurangi angka pengangguran dan kenakalan remaja dengan memberikan informasi tentang lapangan kerja yang dapat dibuka atau dibuat oleh masyarakat Desa Talang Empat dan Desa Taba Terunjam Kecamatan Karang Tinggi Kabupaten Bengkulu Tengah?

2. Bagaimana membantu masyarakat Desa Talang Empat dan Desa Taba Terunjam meningkatkan perekonomian dengan memanfaatkan peluang yang ada?

3. Bagaimana membantu meningkatkan pengetahuan masyarakat terhadap proses-proses produksi yang dapat dimanfaatkan dalam pembangunan dan pengembangan daerah di Desa Talang Empat dan Desa Taba Terunjam Kecamatan Karang Tinggi Kabupaten Bengkulu Tengah?

Program Pelatihan Teknik Pengelasan ini adalah untuk membantu masyarakat daerah pengembangan dalam memenuhi kebutuhan tenaga yang mampu menggunakan mesin atau membuat produk dengan mesin las sehingga pembangunan daerah pengembangan dapat dinikmati oleh masyarakat sekitar. Adapun Tujuan pelatihan pengelasan ini adalah:

1. Untuk memberikan pengetahuan praktis tentang manfaat proses pengelasan dalam memenuhi kebutuhan akan tenaga terampil yang mampu membuat produk dengan proses pengelasan di Desa Taba Terunjam dan Desa Talang Empat Kecamatan Karang Tinggi kabupaten Bengkulu Tengah Provinsi Bengkulu.

2. Memberikan motivasi dalam meningkatkan kemampuan praktis masyarakat dalam menggunakan mesin las untuk menghasilkan produk-produk rumah tangga, kantor dan pelayanan masyarakat di Desa Taba Terunjam dan Desa Talang Empat Kecamatan Karang Tinggi kabupaten Bengkulu Tengah Provinsi Bengkulu.

3. Membantu perekonomian masyarakat dengan membuka lapangan kerja baru sekaligus mengurangi pengangguran pada masyarakat di Desa Taba Terunjam dan Desa Talang Empat Kecamatan Karang Tinggi kabupaten Bengkulu Tengah Provinsi Bengkulu.

Manfaat pelatihan pengelasan ini adalah:

1. Meningkatkan wawasan dan pola fikir masyarakat di Desa Taba Terunjam dan Desa Talang Empat Kecamatan Karang Tinggi kabupaten Bengkulu Tengah Provinsi Bengkulu dalam memanfaatkan potensi (pengelasan) yang ada untuk pembangunan di Bengkulu Tengah.

2. Menambah pengetahuan masyarakat di Desa Taba Terunjam dan Desa Talang Empat tentang proses pengelasan dan penerapan proses pengelasan dalam kehidupan seharihari.

3. Memberi bekal pengetahuan praktis tentang pengelasan sehingga masyarakat di Desa Taba Terunjam dan Desa Talang Empat dapat membuka lapangan kerja sendiri atau bekerja dengan industrik kecil yang ada di Bengkulu Tengah.

4. Memajukan perekonomian desa dan mengurangi angka pengangguran dan kriminalitas. 
Target pelatihan pengelasan ini adalah masyarakat mampu membuat teralis, meja dan kursi, perabotan, pagar dan lainnya dengan menggunakan mesin las. Target lainnya adalah:

1. Untuk memberi perubahan pola fikir dan cara pandang masyarakat terhadap aplikasi atau manfaat besar dari proses pengelasan.

2. Meningkatkan kemampuan praktis masyarakata dalam membuat produk-produk dengan proses pengelasan atau memperbaiki komponen yang rusak dengan proses pengelasan.

Luaran yang dihasilkan dalam pengabdian masyarakat ini adalah pagar, teralis, gerbang dan jenis produk las lainnya seperti ditunjukan oleh Gambar 1, 2, 3 dan 4.

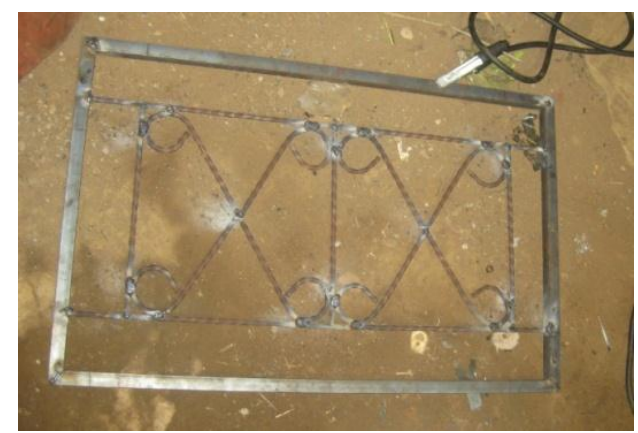

Gambar 1. Produk Pengelasan dengan bahan Besi Siku dan Besi Ulir untuk Teralis

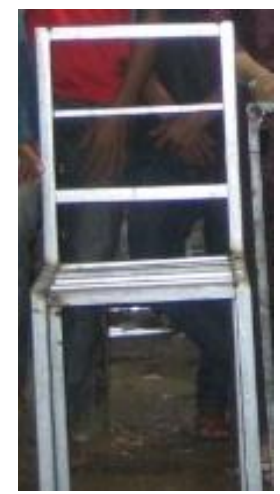

Gambar 2. Model Produk hasil Teknik Pengelasan berupa Kursi Stainless Steel

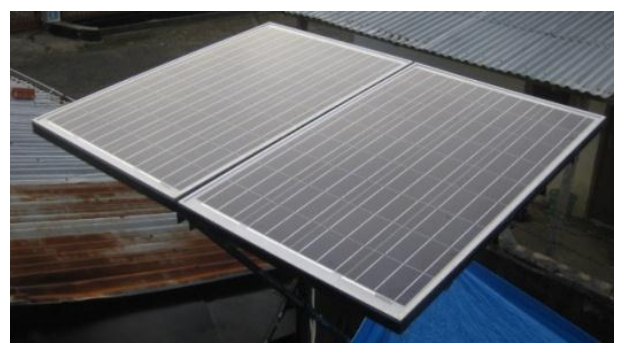

Gambar 3. Model Produk hasil Pengelasan Berupa Rangka Dudukan Sel Surya 


\section{METODE PENGABDIAN}

Metode pelaksanaan program pengabdian masyarakat ini adalah dengan pelatihan penggunaan mesin las (Alip, 1989)(Bintoro, 2005) untuk membuat produk seperti pagar besi, teralis pintu atau jendela dan gapura. Dalam pelatihan ini difokuskan pada dasar pengelasan agar mudah memberikan pengetahuan bagi masyarakat awam. Untuk sasaran dan lokasi penerapan pengabdian masyarakat ini adalah pada Pemuda Karang Taruna Hizbul Watthan di Desa Talang Empat Kecamatan Karang Tinggi dengan melibatkan 30 orang dengan berbagai tahapan sebagai berikut:

\section{a. Tahapan Rencana tindakan}

Penerapan teknologi ini menggunakan metode pendekatan pelatihan campuran. Tahap pertama dengan menggunakan teknik inovasi dan kreatifitas, tahap kedua dengan menggali kemampuan dasar, tahap ketiga dan kempat dengan melakukan uji langsung menghasilkan produk dan melakukan Perawatan/pemeliharaan. Subjek penelitian dalam hal ini adalah remaja putus sekolah dan anak sekolah SMK, dengan langkah-langkah kegiatan sebagai berikut:

1. Kegiatan ini diawali dengan menginterview peserta untuk mengetahui pemahaman mereka tentang Teknik Pengelasan dan proses Pengelasan.

2. Pembimbing memberi pengarahan dan materi tentang Teknik Pengelasan.

3. Berdasarkan data hasil interview dan pengamatan sebelumnya pembimbing mendiskusikan tentang pemahaman Teknik Pengelasan peserta pelatihan.

4. Pembimbing dan peserta berdiskusi rencana keterampilan untuk pertemuan berikutnya.

5. Pembimbing memberi teori dan mempraktekkan teori-teori tersebut

6. Pembimbing memberi kesempatan para peserta untuk berpraktekum perorangan

7. Pembimbing mengamati kemampuan yang telah dimiliki peserta

8. Menetapkan keberhasilan tahapan awal dalam bereksperimen

\section{b. Tahapan Pelaksanaan Tindakan}

Tahapan pelaksanaan tindakan meliputi:

1. Pada tahap pelaksanaan lanjutan dimulai dengan pemberian materi dan informasi Tentang Teknik Pengelasan dan permasalahan yang sering timbul pada saat melakukan Pengelasan.

2. Pembimbing memberi beberapa contoh dalam pelatihan Teknik Pengelasan.

3. Pembimbing memberi pengarahan sekaligus eksperimen Teknik Pengelasan.

\section{c. Tahapan Observasi}

Tahapan observasi meliputi:

1. Pada tahap observasi, kegiatan yang dilakuakan pembimbing adalah mengamati setiap tindakan peserta dalam berekspereimen dan melakukan ujian tertulis tentang pengetahuan yang telah dimiliki.

2. Pembimbing bersama dengan peserta mendiskusikan permasalahan Teknik Pengelasan. 
3. Pembimbing kembali melakukan evaluasi secara tertulis terhadap tindakan yang telah dilakukan peserta.

4. Pembimbing mengidentifikasi hal-hal yang telah dicapai oleh peserta

5. Pembimbing kembali mendiskusikan penyebab terjadinya kekurangan dan merumuskan kembali cara memperbaiki hal-hal yang kurang berhasil.

\section{d. Tahapan Metode Pengumpulan Data Dan Analisa Data}

1. Pengumpulan data tentang proses yang dicapai digunakan observasi dan wawancara

2. Observasi dilakukan untuk mengamati keterampilan peserta secara individual

3. Wawancara digunakan untuk mengetahui tanggapan peserta terhadap keterampilan yang telah dicapai.

4. Data yang telah dikumpulkan akan dianalisa secara deskriptif dan presentase, yaitu suatu analisa data, dimana temuan temuan temuan di diskripsikan kedalam pernyataan-pernyataan. Suatu kesimpulan dapat diambil berdasarkan kecenderungan yang bersifat umum.

Untuk mengukur keberhasilan kegiatan maka dilakukan evaluasi dengan tahapan sebagai berikut:

1. Pengumpulan data tentang proses yang dicapai digunakan observasi dan wawancara

2. Observasi dilakukan untuk mengamati keterampilan peserta secara individual

3. Wawancara digunakan untuk mengetahui tanggapan peserta terhadap keterampilan yang telah dicapai.

4. Data yang telah dikumpulkan akan dianalisa secara deskriptif dan presentase, yaitu suatu analisa data, dimana temuan temuan-temuan di diskripsikan kedalam pernyatanpernyataan. Suatu kesimpulan dapat diambil berdasarkan kecenderungan yang bersifat umum.

5. Data tentang keterampilan akan dikategorikan, rendah sedang, tinggi,. Kategori rendah jika tingkat keberhasilannya mencapai kurang dari $20 \%$, sedang jika tingkat keberhasilannya adalah 40\%-80\%, tinggi jika 74\% - 99\%.

6. Diharapkan setelah pelatihan ini akan membuka lapangan kerja baru serta mendapatkan pekerjaan dengan kemampuan yang dimiliki lebih kurang 75\%. 


\section{HASIL DAN PEMBAHASAN}

\section{Hasil Pelatihan Proses Pengelasan}

Pelatihan proses pengelasan diawali dengan pengenalan alat-alat las dan peralatan bantu proses pengelasan, benda yang akan dibuat dengan proses las dan jenis-jenis mesin las serta bentuk kampuh las. Alat-alat yang digunakan adalah mesin las TIG yang dapat membuat produk las dari metal maupun stainless steel, mesin gerinda tangan untuk proses potong dan finishing, elektroda, palu, cat dan lainnya yang dapat dilihat pada Gambar 4.

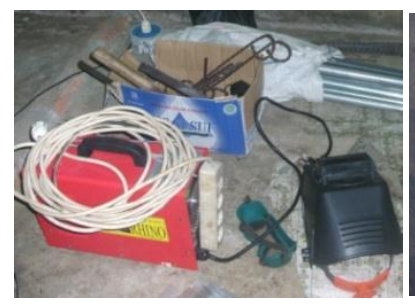

a. Mesin Las

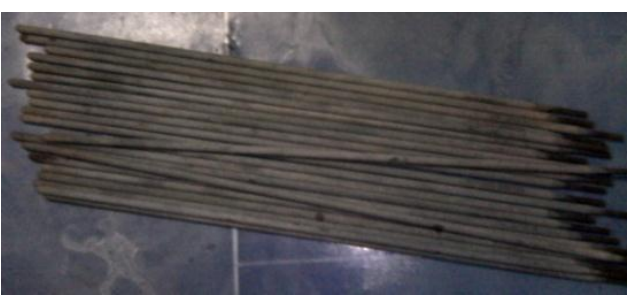

b. Elektroda

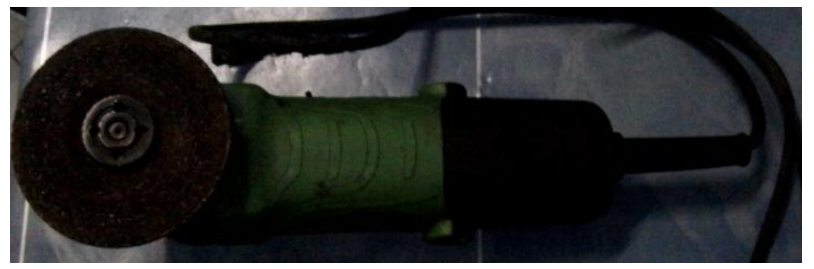

c. Mesin Gerinda Tangan

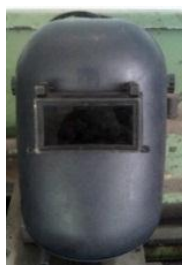

d. Pelindung

Gambar 4. Mesin Las, Mesin Gerinda dan Alat Pelindung

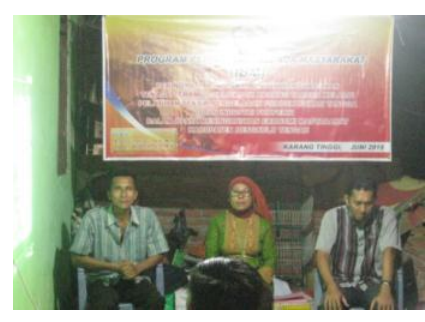

a. Sambutan Kepala Desa Taba Terujam

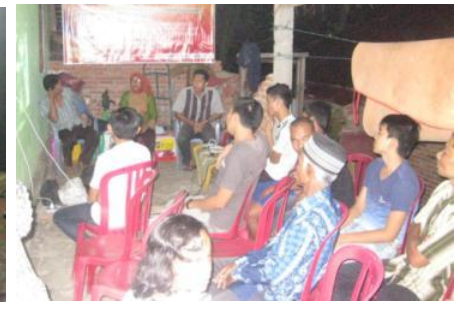

b. Peserta Pelatihan Desa Taba Terujam

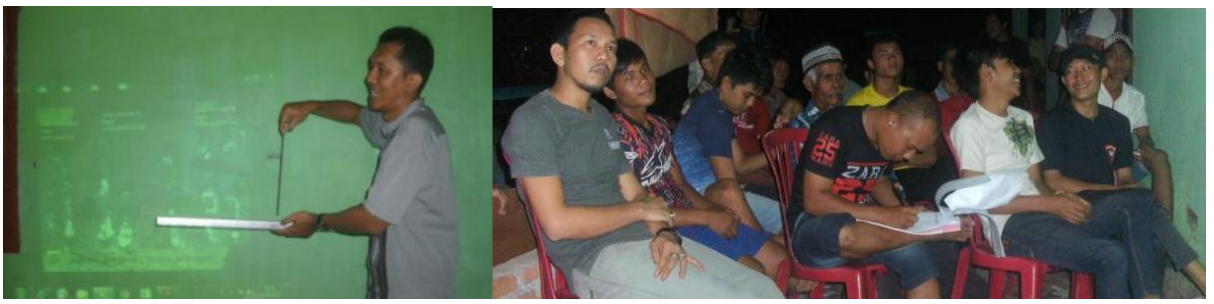

c. Penyampaian Materi Pengelasan

Gambar 5. Proses Pemberian Materi Pelatihan Pengelasan

Gambar 5 menunjukan proses pelatihan yang diberikan dimana kegiatan dibuka secara resmi oleh Kepala Desa (Sekretaris Desa) dan dihadiri oleh masyarakat. Pemberian materi berupa tahapan proses pengelasan, cara-cara pengelasan, penggunaan alat bantu dan 
pengaman dijelaskan dalam pelatihan ini seperti ditunjukan oleh Gambar 5c. Produk yang akan dibuat dan dihasilkan dalam pelatihan ini adalah berupa teralis, kursi stainless steel dan rangka dudukan solar sel dari besi siku seperti terlihat pada Gambar 1 hingga Gambar 3.

Selesai pemberian materi dilanjutkan dengan praktek penggunaan mesin las untuk membuat produk berupa teralis. Pertama dipersiapkan semua peralatan seperti mesin las, elektroda, bahan yang akan dibuat, alat bantu dan pengamanan pada proses pengelasan. Persiapan alat pengelasan. Selanjutnya pembuatan produk teralis dimulai dari persiapan alat seperti mesin las, sarung tangan, pelindung mata, elektroda, kabel dan material las dan dilanjutkan dengan pelatihan. Pada saat pelatihan, peserta harus menggunakan fasilitas pengaman seperti sarung tangan, kaca mata las dan lainnya agar peserta aman dan tidak mengalami kecelakaan saat menggunakan mesin las seperti terlihat pada Gambar 7. Dari hasil pengelasan yang dilakukan peserta, terlihat beberapa peserta sudah dapat menggunakan mesin las untuk membuat atau menyambung suatu benda.
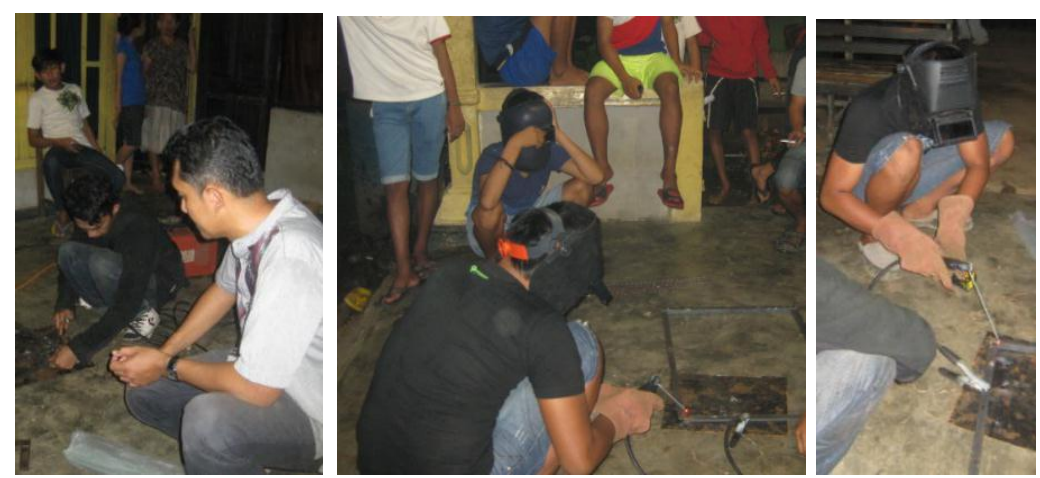

a. Pembuatan Sudut 90 pada Pengelasan Rangka Teralis
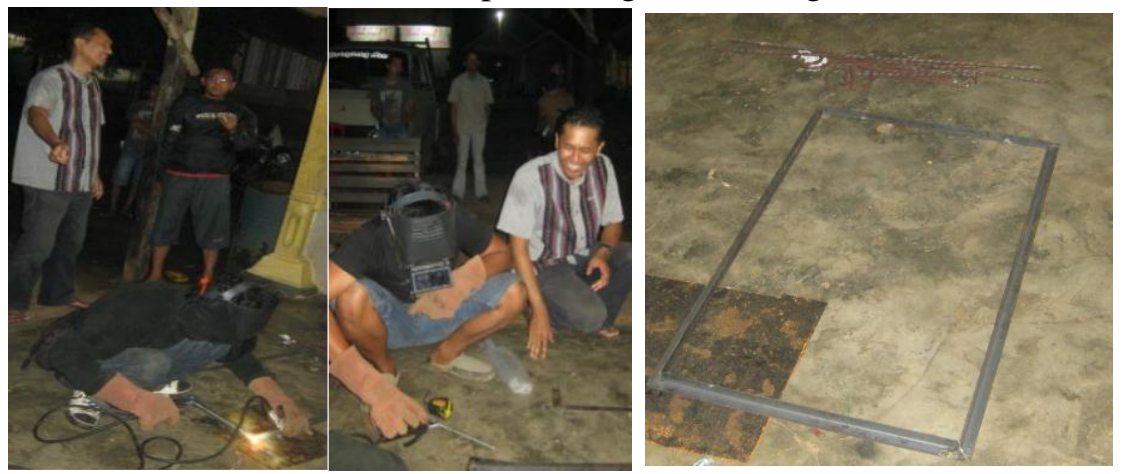

b. Pengelasan Rangka Teralis

Gambar 6. Proses Pelatihan Pengelasan di Desa Taba Terujam

Untuk pelatihan di Desa Talang Empat dilakukan pengelasan pembuatan teralis, kursi dan dudukan rangka panel solar sel. Proses pelatihan juga diawali dengan pemberian materi yang dihadiri oleh 20 pemuda dan dibuka oleh Kepala Desa Talang Empat. Proses pemberian 
materi pengelasan dan pembukaan kegiatan pelatihan oleh Kepala Desa dapat dilihat pada Gambar 7.

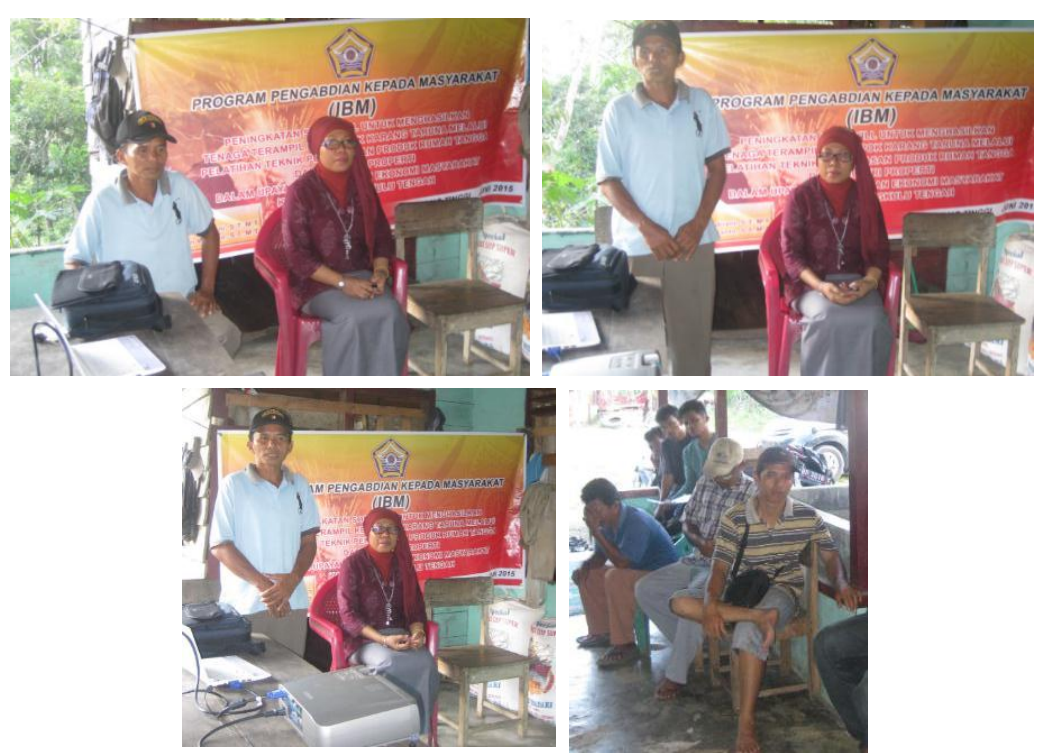

Gambar 7. Pembukaan Pelatihan Pengelasan di Desa Talang Empat

Setelah pembukaan oleh Kepala Desa Talang Empat dilanjutkan dengan pemberian materi tentang teori dasar pengelasan, simbol-simbol pengelasan, cara pengelasan besi pejal dan hollow, mesin dan alat-alat yang digunakan untuk proses pengelasan. Proses pemberian materi teori dasar pengelasan dapat dilihat pada Gambar 8. Peserta yang mengikuti pelatihan ini dapat dilihat pada Gambar 9.

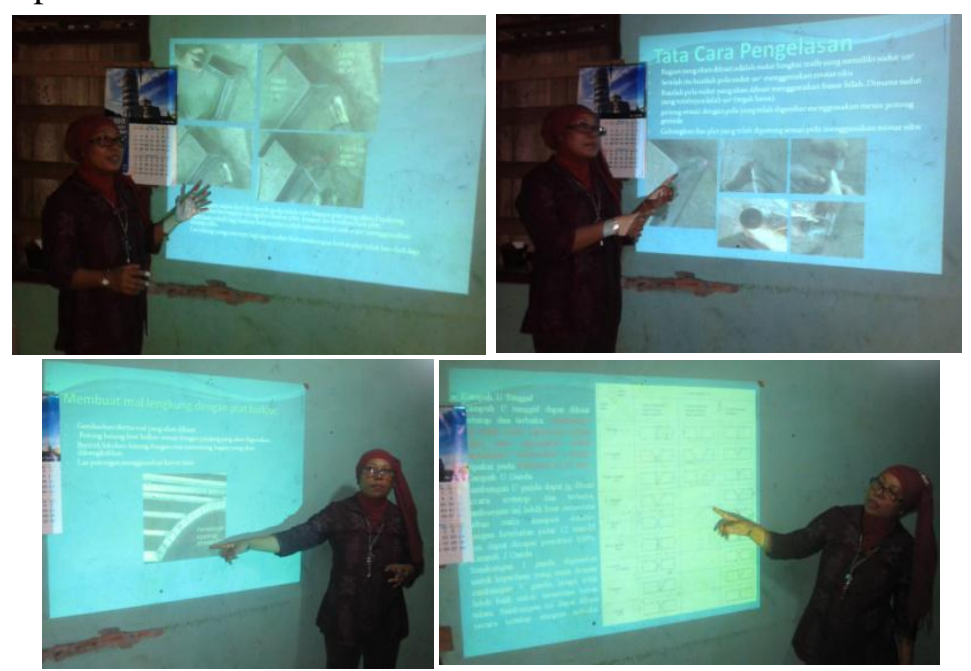

Gambar 8. Proses Pelatihan Teori Dasar Pengelasan di Desa Talang Empat 

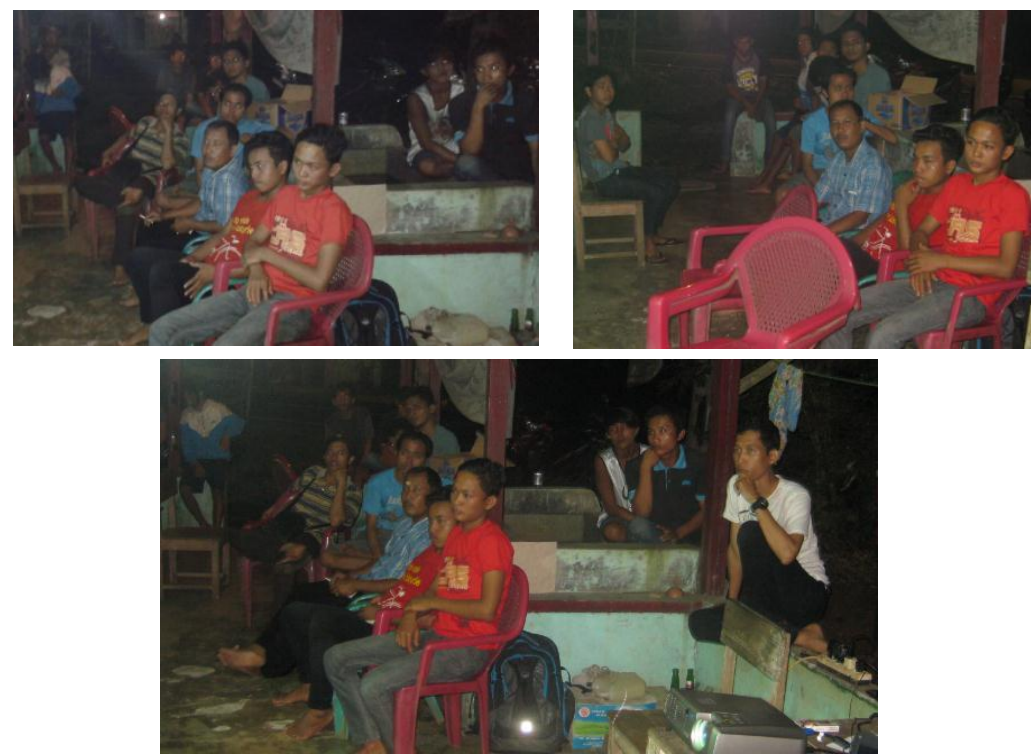

Gambar 9. Peserta Pelatihan Pengelasan di Desa Talang Empat

Setelah pemberian materi kegiatan pelatihan dilanjutkan dengan praktek pengelasan membuat teralis, kursi dari material stainless steel dan rangka dudukan panel surya. Pada pelatihan ini setiap peserta mencoba membuat alat secara bergiliran. Proses pembuatan teralis dapat dilihat pada Gambar 10. Gambar 10 a menunjukan proses pembuatan sudut siku pada teralis dan pemasangan besi ulir untuk bagian dalam teralis (lihat Gambar $10 \mathrm{~b}$-d).
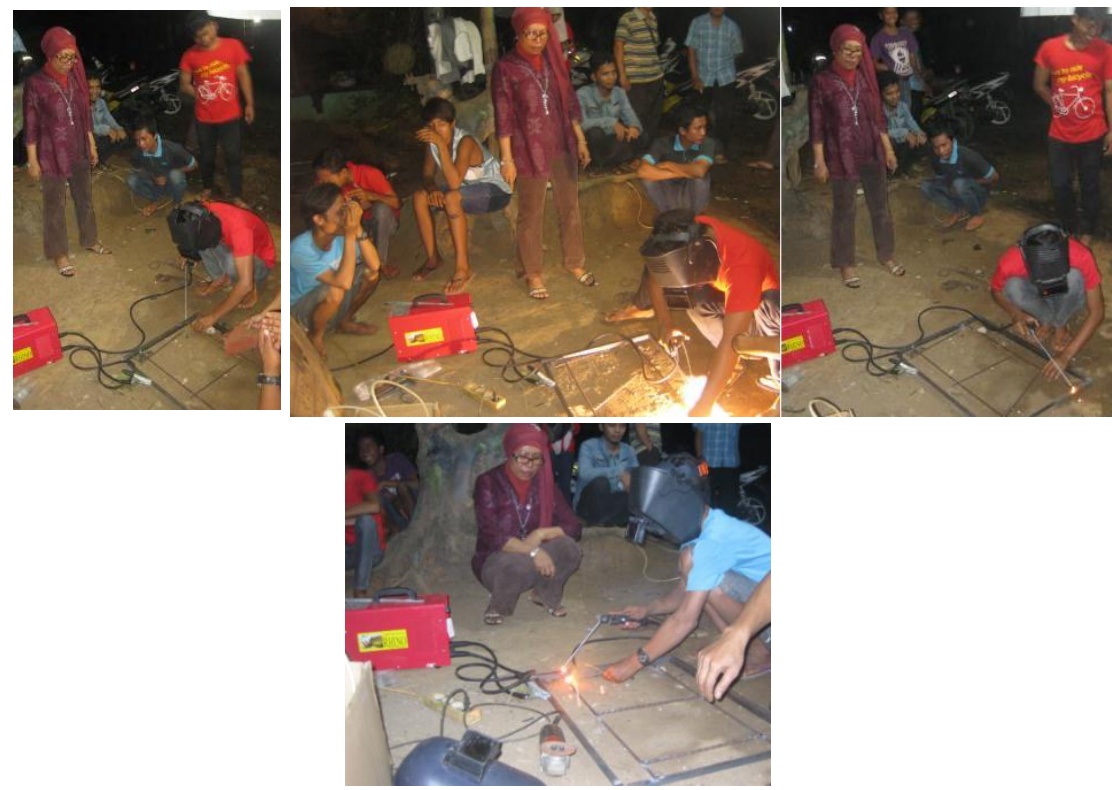

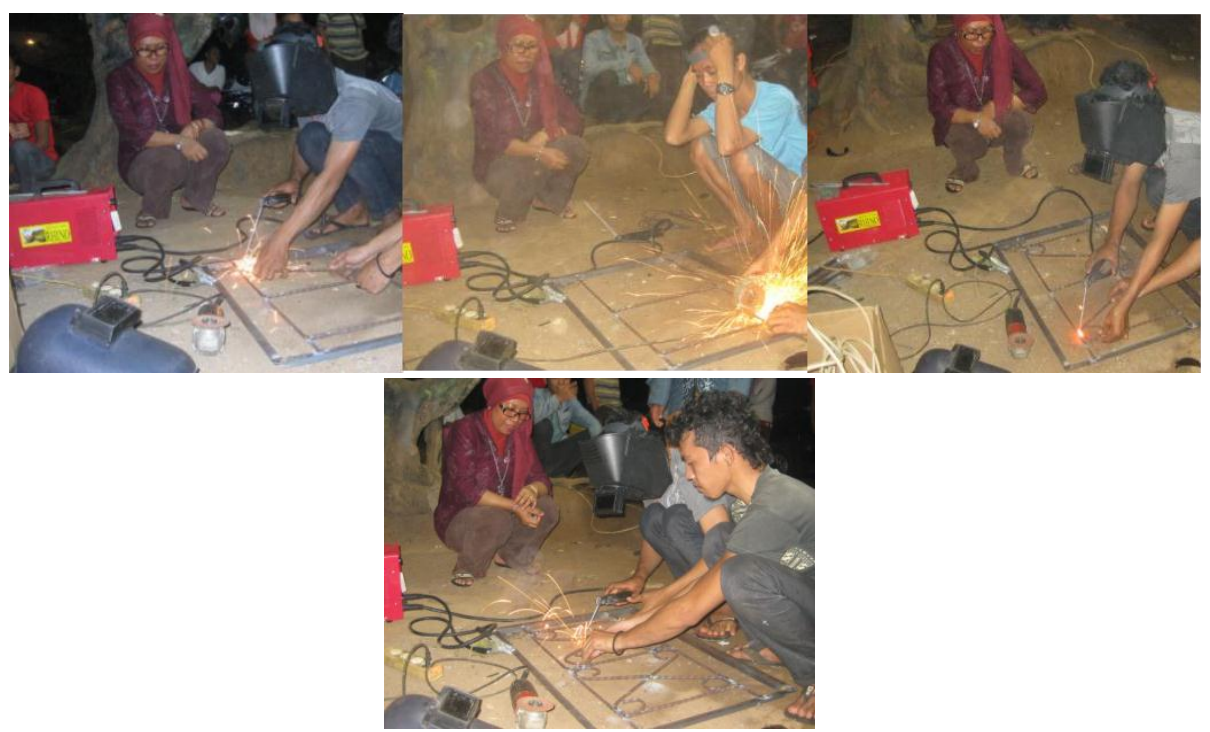

Gambar 10. Proses Praktek Pengelasan Pembuatan Teralis di Desa Talang Empat

Selanjutnya pada Gambar 10 e hingga Gambar 10 g produk atau bahan dilas menjadi bentuk corak teralis yang diinginkan. Hasil akhir pengelasan teralis ini dapat dilihat paga Gambar 11.

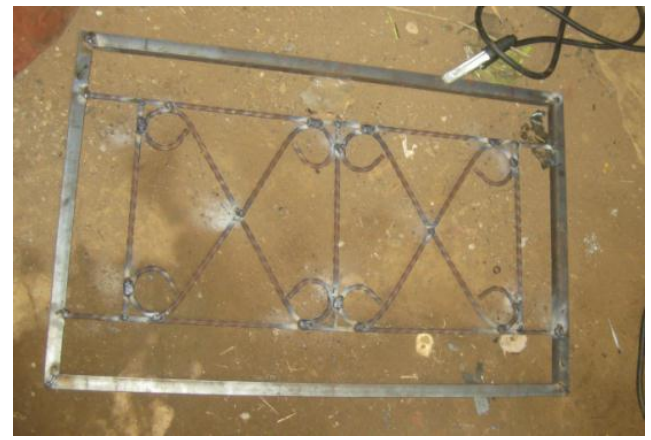

Gambar 11. Produk Pengelasan Teralis

Setelah pembuatan teralis dilanjutkan dengan pembuatan kursi dengan pengelasan stainless dan pembuatan rangka dudukan panel surya. Proses pembuatan kursi dapat dilihat pada Gambar 12 dan hasilnya dapat dilihat pada Gambar 13.

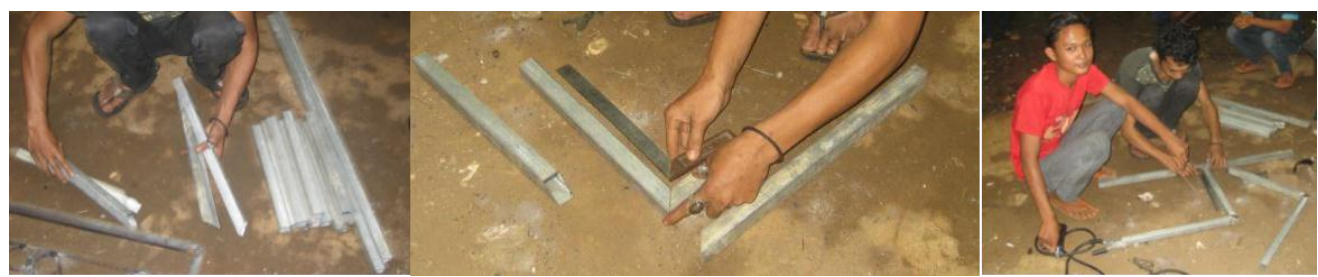

a. Pemotongan Stainless Hollow dan Persiapan Pengelasan 


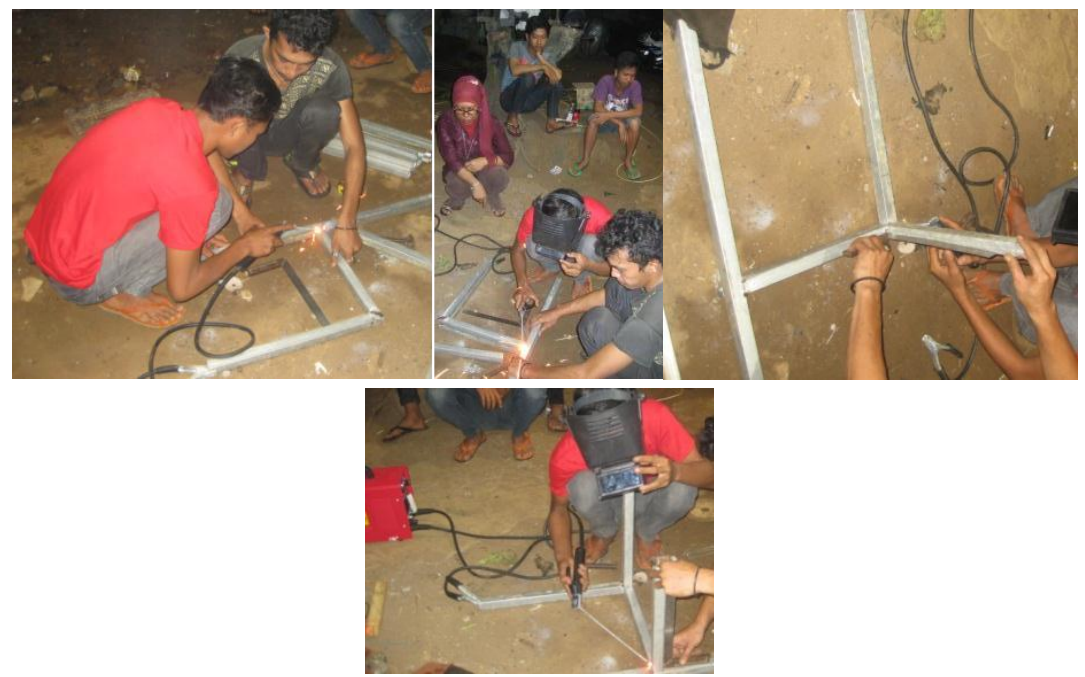

b. Pengelasan Siku untuk Pembuatan Kursi Stainless Steel
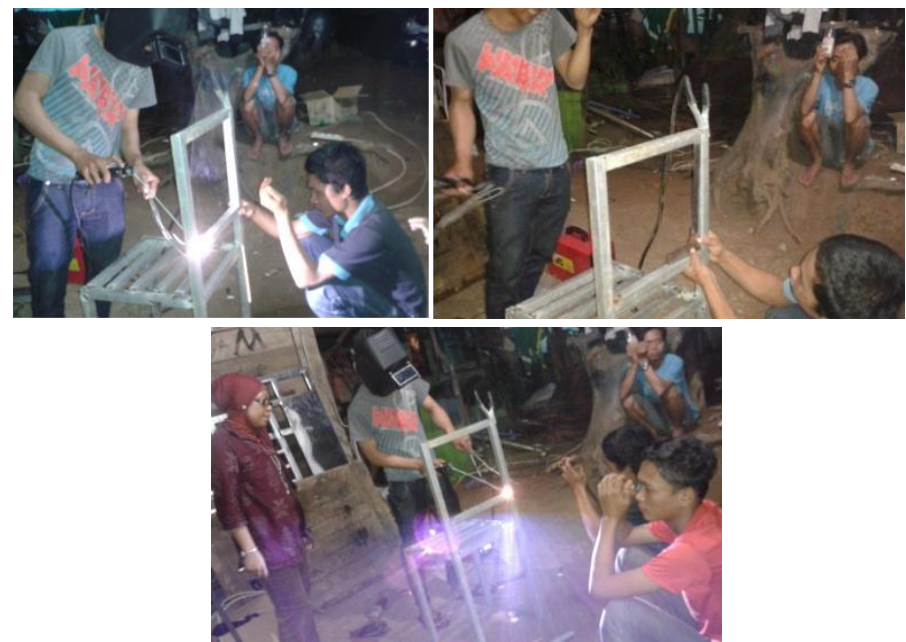

c. Pembuatan Dudukan Kursi
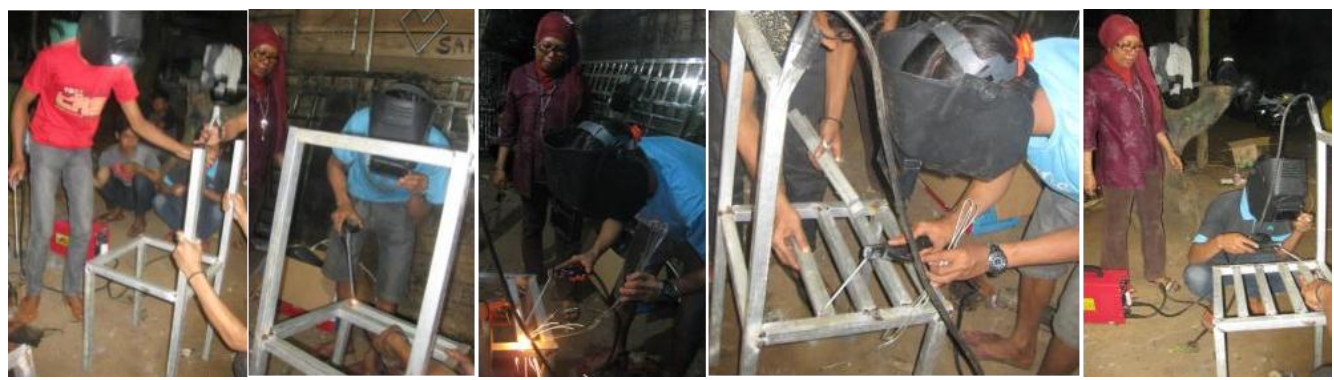

d. Finishing Hasil Las

Gambar 12. Praktek Pengelasan Pembuatan Kursi di Desa Talang Empat 


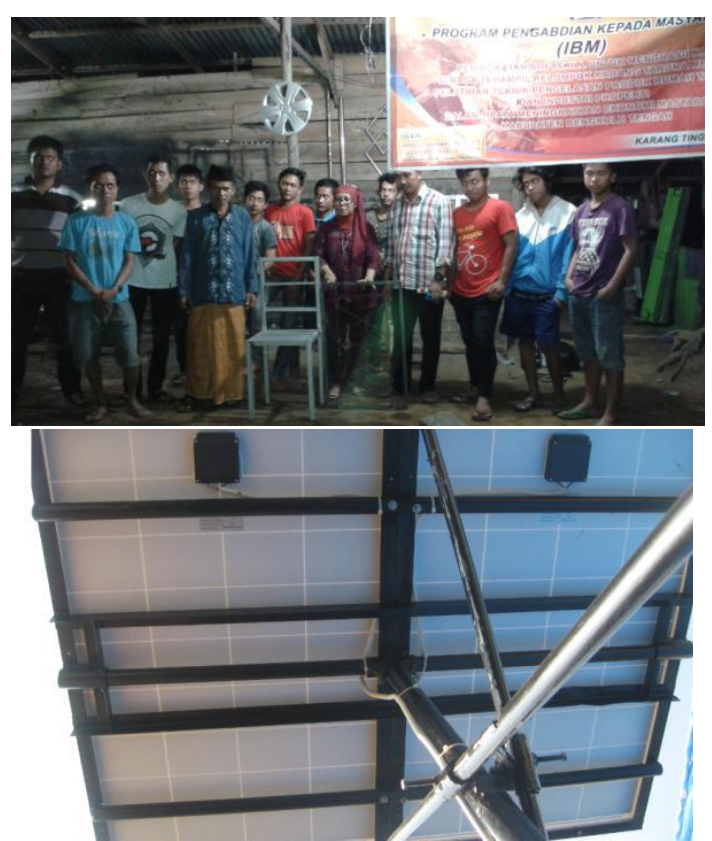

Gambar 13. Produk Pengelasan Kursi dan Panel Surya

\section{Hasil Pelatihan Bagi Masyarakat}

Pelatihan yang telah dilaksanakan dan respon masyarakat dalam mengikuti pelatihan ini sangat besar. Dimana semua peserta terlihat dengan tekun mengikuti arahan yang diberikan. Hal ini mungkin disebabkan oleh keinginan masyarakat untuk mendapatkan pengetahuan yang baru tentang pengelasan dan aplikasinya dilapangan. Dari hasil pelatihan ini $95 \%$ masyarakat mampu menggunakan mesin las dan membuat produk rumah tangga dengan proses pengelasan dan menginginkan kelanjutan dalam pelatihan ini untuk membuat komponen atau produk las yang lain.

Keinginan masyarakat ini timbul karena melihat banyaknya keuntungan jika bisa menggunakan mesin las untuk membuat sesuatu benda yang berguna dalam kehidupan sehari-hari seperti pembuatan pagar, teralis, papan nama dan lainnya. Selain dapat membuat benda dengan mesin las, pengetahuan pengelasan ini juga akan menambah pemasukan masyarakat dengan cara membuka bengkel kecil atau bergabung dengan bekerja pada bengkel yang sudah ada. 


\section{KESIMPULAN DAN SARAN}

\section{Kesimpulan}

Dari pelatihan pengelasan yang diperoleh beberapa kesimpulan yaitu:

1. Peserta pelatihan mampu menggunakan mesin las untuk membuat produk rumah tangga ataupun kebutuhan kantor berupa teralis, kursi dan dudukan sel surya.

2. Masyarakat dapat membedakan penggunaan mesin las TIG dan MIG untuk produk yang dibuat seperti penggunaan las MIG untuk teralis dan TIG untuk pengelasan stainless Steel.

3. $95 \%$ masyarakat atau peserta pelatihan dapat menggunakan mesin las untuk membuat produk yang diinginkan.

\section{Saran}

Sebaiknya pelatihan ini dilakukan secara kontinu untuk membuat produk yang lain dimana dengan penerapan langsung praktek masyarakat lebih cepat menerima hasil pelatihan.

\section{DAFTAR PUSTAKA}

Ahmad, Rafiq dan Johnny Hasman, 1994, Pengaruh Panas Pengelasan pada Daerah HAZ terhadap Kekerasan Baja VCN, Lembaga Penelitian USU, Medan.

Alip, Mochamad, 1989, Teori dan Praktik Las, Departemen Pendidikan dan Kebudayaan, Jakarta.

Amanto, Hari, 1999, Ilmu Bahan, Bumi Angkasa, Jakarta.

Arifin, S, 1997, Las Listrik Dan Otogen, Ghalia Indonesia, Jakarta.

Bintoro, A. Gatot, 2005, Dasar-Dasar Pekerjaan Las, Kanisius, Yogyakarta.

Harsono, Wiryosumarto, Toshie Okumura, 2008, Teknologi Pengelasan Logam, Pradnya Paramita, Jakarta.

Suharto, 1991, Teknologi Pengelasan Logam, Rineka Cipta, Jakarta. 
